UDC 339.7

DOI: https://doi.org/10.32782/2413-9971/2020-34-17

Kapranova Olena

Student

Odesa I. I. Mechnikov National University

Rodionova Tetiana

Candidate of Economic Sciences, Associate Professor,

Senior Lecturer at Department of World Economy and International Economic Relations

Odesa I. I. Mechnikov National University

Капранова О. О.

студент

Одеського національного університету імені I. І. Мечникова

Родіонова Т. А.

кандидат економічних наук, доиент,

доцент кафедри світового господарства і міжнародних економічних відносин,

Одеський національний університет імені I. І. Мечникова

\title{
ANALYSIS OF THE RETURN ON FOREIGN INVESTMENT OF THE UNITED KINGDOM AND IRELAND
}

Summary. International capital flows have significant potential benefits for economies around the world. With the intensification of globalization processes and the increase in the scale of international capital movements, the role of foreign direct investment as an important factor in economic development is growing significantly. Due to the attraction of foreign investments, there are opportunities for modernization of production, creation of additional jobs, increase of tax revenues. This article analyses the theoretical foundations of the analysis of the return on investment, determines the coverage ratios of foreign investment, which were attracted to countries and exported from countries. The return on investment is also determined. An analysis of the results of modeling the dependence of GDP and capital flows obtained by the United Kingdom and Ireland during the study period shows that there is an interdependence between Ireland's GDP and the country's capital flows from both direct investments and portfolio investments.

Key words: the United Kingdom, direct investments, Ireland, portfolio investments, return on investment, other investments.

Introduction and formulation of the problem. International capital flows have significant potential benefits for economies around the world. Countries with sound macroeconomic policies and well-functioning institutions are in a better position to benefit from capital flows and minimize risks. The United Kingdom is one of the most highly industrialized countries in the world. The country occupies a high position in international rankings, belongs to the countries with a high level of economic development. The UK economy ranks fifth in the world in terms of GDP. Ireland 
is a progressively developing agro-industrial country. Due to its small size, the Irish economy is heavily dependent on foreign trade. The pharmaceutical industry and information industry are developing rapidly in the country, the country attracts large amounts of investment. Both countries attract significant amounts of investments.

Analysis of recent research and publications. International capital flows have significant potential benefits for economies around the world. Countries with sound macroeconomic policies and well-functioning institutions are in a better position to benefit from capital flows and minimize risks.

With the intensification of globalization processes and the increase in the scale of international capital movements, the role of foreign direct investment as an important factor in economic development is growing significantly.

Due to the attraction of foreign investments, there are opportunities for renewal and modernization of production, creation of additional jobs, an increase of tax revenues, and a general increase of competitiveness of the national economy.

Foreign investment is an investment made by residents of one country in the financial assets and production process of another country. After the opening of borders for the movement of capital, these investments were skyrocketing. But it had different consequences in different countries. In developing countries, there is an urgent need for foreign capital to not only increase productivity but also to help create foreign exchange reserves to cover the trade deficit. Foreign investment provides a channel through which these countries can access foreign capital. It can be of two types: foreign direct investment (FDI) and foreign portfolio investment (FDI). While the former leads to the creation of physical infrastructure, the latter is invested in financial markets [1, p. 1].

The hypothesis of the study, put forward by the authors of the article "Foreign direct investment and the lack of positive effects on the economy" was to prove that along with some positive effects of foreign direct investment, there are negative, which was also proved by various authors [2, p. 198]

So the authors decided to investigate the effects of foreign investment on the country's economy on the example of Croatia. Through a structural analysis of foreign direct investment in Croatia between 1993 and the third quarter of 2014, it was found that Croatia received just over 19 billion EUR in foreign direct investment.

Despite this fact, there have been very few positive effects from foreign investment in Croatia, and therefore economic indicators have not changed or improved. Income from foreign direct investment was mainly used to repay financial debts. The analysis of foreign direct investment and its impact on GDP, employment, and exports was conducted using a linear regression model. Such an analysis, especially as to whether one of the assumptions has been invalid, is insufficient to draw a definitive conclusion about the impact of foreign direct investment on economic growth. Based on the results, which partially contradicted the economic theory, it can be concluded that the problem lies in the structure of foreign direct investment, with special emphasis on investment in the green field. The conclusions of this document do not mean that Croatia should stop encouraging the inflow of foreign direct investment, but they suggest that changes in the strategy of attracting foreign direct investment are necessary. When it comes to foreign direct investment, Croatia's priority should be to attract new investment in a new production to increase jobs, exports, and, consequently, economic growth and development. Thus, Croatia can achieve a positive impact on foreign direct investment, and the competitiveness of the Croatian economy can improve [2, p. 201-207].
A similar analysis was conducted by Eduard Davketshin, the author of the article "Quantitative and Qualitative Analysis of Foreign Direct Investments in Developed and Developing Countries". But the author, in addition to determining the statistical relationship between economic growth and FDI, explains that there is also the task of identifying the level of influence of key factors determining the growth of FDI on GDP. The following factors should include wage levels, country size, natural resources, political and macroeconomic factors, taxes, and other factors that determine the investment climate [3, p. 256].

The results of the analysis show that indeed developed countries attract high levels of FDI, but this does not have as strong an impact on GDP and economic growth as in developing countries, especially in the BRICS countries. The conclusions can be summarized as follows:

- Developed countries are less dependent on FDI inflows than developing countries;

- The share of developing countries in global FDI inflows is growing, while in developed countries it is declining;

- Higher growth rates in developing countries, the availability of resources, and high returns on investment may explain the increase in their share of global FDI [3, p. 263].

Using empirical research methods, the authors of the article "Foreign Direct Investment and Economic Growth in the Short Run and Long Run: Empirical Evidence from Developing Countries" -Trang Thi-Huyen Dinh - also examine the impact of foreign direct investment on economic growth, using indicators from 30 developing countries in the period 2000-2014 [4, p. 1].

The study contributes to the literature on the relationship between FDI and growth in developing countries, focusing on these relationships in both the short and long term over an important period from 2000 to 2014, which includes the global financial crisis.

The empirical results of the study can be summarized as follows. Firstly, FDI capital flows can hinder a country's economic growth in the short run, but can also have a positive effect in the long run. Secondly, domestic credit to the private sector has a negative impact on economic growth in the short run, while it is determined that the money supply will have a positive effect in both the short and long term for economic growth. Human capital, total domestic investment, and domestic credit for the private sector have a positive impact on economic growth in the long run. As a result, it can be argued that FDI is an important factor for economic growth in the long run, especially for countries with developing economies. Efforts to attract FDI in addition to domestic investment in developing countries with below-average incomes should be encouraged. However, it should be borne in mind that the policy of attracting FDI should be developed with a long-term perspective to maximize the positive impact of FDI on the country's economy. Policies aimed at attracting FDI at all costs in the short term will not bring fundamental benefits to the economy. Developing countries with below-average incomes are trying to attract FDI to achieve positive results. The impact of FDI on economic growth is not always positive, as it depends on the characteristics of FDI investment, such as type, sector, volume, duration, the share of domestic business in the sector, etc. Governments should take measures to improve the quality of human resources and labor skills. Because FDI is always accompanied by technology, it requires highly skilled labor to use new technology and create a positive effect of technological diffusion. At the same time, in addition to prioritizing FDI attraction, governments should examine policies on human capital, money supply, overall domestic investment, and overall credit to the private sector 
to accelerate economic growth and maximize FDI benefits. The money supply always has a positive effect on accelerating economic growth in both the short and long term. Therefore, the development and flexible use of monetary policy to support growth should be a priority. Despite the efforts made in the study, certain limitations can be avoided. Firstly, the period used in this study may not be sufficient for econometric research on macroeconomic subjects (usually 15 years). Secondly, the presence of a global economic crisis during the period used in this paper may lead to economic and political instability in emerging markets [4, p. 9].

The positive impact of foreign direct investment (FDI) on countries with economies in transition has been widely acknowledged, the authors of the scientific article "Foreign Direct Investment Financing of Capital Formation in Central and Eastern Europe" say. Firstly, FDI is an important source of funding for transition economies because it helps cover current account deficits, budget deficits (in the case of privatizationrelated FDI) and complements inadequate domestic resources to finance both change of ownership and capital formation. Secondly, compared to other FDI financing options, they also facilitate the transfer of technology, know-how, and skills and help local businesses to enter foreign markets $[5, \mathrm{p} .1]$

This study addresses the following question: How important is FDI in financing capital formation in transition economies compared to other forms of corporate financing (domestic and external credit, capital market financing, and government subsidies)? The potential importance of foreign direct investment for capital accumulation in transition economies is underscored by the need to replace the large amount of obsolete capital accumulated over years of centralized planning in the absence of an efficient financial sector.

The role of FDI in financing capital formation is unclear. The definition of foreign direct investment is focused on the source of capital with little regard for its use. Indeed, researchers find little evidence that FDI affects capital accumulation in developed countries, and shows that the most important aspect of FDI in a selected sample of countries is related to changes in ownership [5, p. 1].

The empirical results of the study showed that FDI, domestic credit, and local capital markets are important sources of financing for capital formation, with FDI having a much greater impact than domestic lending and financing in the capital market, although no such link can be found for government subsidies and foreign credit. It has also been shown that foreign direct investment replaces domestic credit, while foreign credit has a direct link with FDI, taking into account the economic situation. The empirical analysis also confirmed the results of the literature related to the significant importance of natural resources and privatization proceeds as determinants of foreign direct investment. Empirical analysis has some political implications. Improving the investment climate, which contributes to attracting more FDI inflows, will increase gross fixed capital formation, which in turn will accelerate economic growth. This is more important in countries with economies in transition, which are not endowed with natural resources, and in countries with economies in transition, which have few state assets left for privatization [5, p. 18].

This study aims to conduct a comparative analysis of the return on foreign investment of the United Kingdom and Ireland.

Presentation of the main research material. Determining the coverage ratios of foreign investments attracted to the country and their profitability. Based on data on attracting foreign investment in the UK and Ireland, the following calculations were made (Table 1).

Table 1

Structure of exported investment
income 2005-2019, bln. USD
\begin{tabular}{|l|c|c|c|}
\hline Country & FDI & Portfolio & Other \\
\hline $\begin{array}{l}\text { United } \\
\text { Kingdom }\end{array}$ & $2061.7(43.6 \%)$ & $1282.9(27.2 \%)$ & $1382.1(29.2 \%)$ \\
\hline Ireland & $275.9(21.9 \%)$ & $662.5(52.7 \%)$ & $318.9(25.4 \%)$ \\
\hline
\end{tabular}

Source: author's calculations [7]

Analysis of the data showed that in the UK from 2005 to 2019 , the share of foreign direct investment in total exported revenues is $43.6 \%$, thus the share of direct investment is the largest in total exported revenues. The share of portfolio and other investments in the total amount of exported revenues is $27.2 \%$ and $29.2 \%$, respectively.

In Ireland, over the same period, the share of direct investment was $21.9 \%$, and the share of other investment in total exports was $25.4 \%$. In turn, the share of portfolio investment in the period 2005-2019 was $52.7 \%$, which indicates that in Ireland, interest payments on portfolio investments, which account for half of the total income outflows, predominate.

According to the formula, introduced by $\mathrm{T}$. Rodionova, the return on foreign investment attracted to the United Kingdom and Ireland was calculated. The calculation is the ratio of payments of investment income by the country in foreign currency (debit of the current account income on liabilities of type $\mathrm{X}$ - direct, portfolio, or other investments) to the accumulation of external liabilities of type $X[6, p .46]$. The results are presented in Table 2 .

Table 2

The average value of the return on investment from 2005 to $2019, \%$

\begin{tabular}{|l|c|c|c|}
\hline \multicolumn{1}{|c|}{ Country } & FDI & Portfolio & Other \\
\hline United Kingdom & 6.54 & 2.78 & 1.52 \\
\hline Ireland & 2.43 & 2.22 & 2.04 \\
\hline
\end{tabular}

Source: author's calculations [7]

After receiving the results of calculating the average value of return on investment (Table 2) from 2005 to 2019, it was found that the highest return was obtained by foreign investors on direct investment in the UK (6.54\%). Foreign investors received the lowest returns from other investments in the UK, at $1.52 \%$. In turn, the return on the direct, portfolio, and other investments in Ireland is almost at the same level.

Table 3

The share of total income exported by foreign investors in the relevant cumulative receipts of the financial account (foreign investment coverage ratio), 2005-2019

\begin{tabular}{|l|c|c|c|c|c|c|}
\hline \multicolumn{1}{|c|}{ Country } & FDI & Portfolio & Other & $\begin{array}{c}\text { Total exported } \\
\text { revenues, billion } \\
\text { dollars }\end{array}$ & $\begin{array}{c}\text { Cumulative financial } \\
\text { account receipts, billion } \\
\text { dollars }\end{array}$ & $\begin{array}{c}\text { The share of exported } \\
\text { revenues in total revenues }\end{array}$ \\
\hline United Kingdom & $177.66 \%$ & $293.57 \%$ & $82.89 \%$ & 4740.8 & 3264.8 & $145.21 \%$ \\
\hline Ireland & $37.99 \%$ & $30.16 \%$ & $41.45 \%$ & 1257.4 & 3692.2 & $34.05 \%$ \\
\hline
\end{tabular}

Source: author's calculations [7] 
In the United Kingdom, portfolio payouts predominate and account for $293.57 \%$ of the capital received (Table 3 ). Investment payments on direct investments in the period 2005-2019 amounted to $177.66 \%$, the lowest percentage falls on investment payments on other investments $-82.99 \%$. A total of 4.7 billion USD in foreign investment income was exported from the UK between 2005 and 2019, while the country received 3.2 billion USD.

In turn, a total of almost 1.3 billion USD in investment income was exported from Ireland and during this period received almost 3.7 billion USD. The coverage ratio is $34.05 \%$. In Ireland, investment payments for other investments predominate and this figure is $41.45 \%$ of the capital received. Payments on direct investments are $37.99 \%$ and the smallest share of payments falls on portfolio investments $-30.16 \%$.

Determination of coverage ratios of foreign investments exported from countries and their profitability. The following calculations were made based on data on foreign investment from the United Kingdom and Ireland (Table 4).

Structure of imported investment

Table 4 income 2005-2019, bln USD

\begin{tabular}{|l|c|c|c|}
\hline Country & FDI & Portfolio & Other \\
\hline $\begin{array}{l}\text { United } \\
\text { Kingdom }\end{array}$ & $2061.7(43.6 \%)$ & $1282.9(27.2 \%)$ & $1382.1(29.2 \%)$ \\
\hline Ireland & $275.9(21.9 \%)$ & $662.5(52.7 \%)$ & $318.9(25.4 \%)$ \\
\hline
\end{tabular}

Source: author's calculations [7]

Analyzing the data, it should be noted that in the US from 2005 to 2019, the share of foreign direct investment in total imported income is $25.6 \%$, the share of portfolio investment is $42.7 \%$, and the share of other investment is $31.7 \%$. In the UK, interest rates on portfolio investments predominate, while direct investment returns are the lowest.

Ireland's share of direct investment in total imports is $45.5 \%$. Income from portfolio investments is $38.5 \%$. Income from other investments placed abroad is the lowest - $16 \%$ of the total imported income.

Table 5

The average value of the return on imported investments from 2005 to $2019, \%$

\begin{tabular}{|l|c|c|c|}
\hline \multicolumn{1}{|c|}{ Country } & FDI & Portfolio & Other \\
\hline United Kingdom & 6.54 & 2.78 & 1.52 \\
\hline Ireland & 5.27 & 3.85 & 1.74 \\
\hline
\end{tabular}

Based on the obtained calculations (Table 5), the highest return on foreign investment for the study period 2005-2019 was obtained by the British investors on direct investment abroad $(6.54 \%)$. The rate of return on direct investment in Ireland is $5.27 \%$. The least British investors received from other investments; this figure is $1.52 \%$. Therefore, it should be concluded that investors in the UK and Ireland have the highest returns on foreign direct investment abroad.
After analyzing certain categories of investment, it should be noted that the UK in the period 2005-2019 was imported a total foreign investment income of 5.13 trillion USD. At the same time, 5.14 trillion USD came from the country during the same period, the coverage ratio was $99.7 \%$. Payments to the British investors for direct investment account for the lowest percentage $-73.75 \%$. Payments on portfolio investments account for $79.02 \%$ of exported capital. The largest percentage is occupied by investment payments on other investments $274.82 \%$ of exported capital.

Nominally, Ireland has invested 1.9 billion USD in the national capital in 2005-2019. If we pay attention to the structure of imported income, the share of payments on direct investment is $111.90 \%$ - this is the largest figure. Payments on other investments are $39.07 \%$ and the lowest percentage falls on portfolio investments and is $30.51 \%$.

To investigate the causality between received flows of foreign capital (direct, portfolio, and other investments) and GDP, the following vector autoregression model (VAR) is constructed. GDP $t$ - the U.S. GDP, German GDP, Japan GDP, million USD; INVtype $t$ - the type of foreign investment (direct, portfolio, and others), million USD.

The model of vector autoregression is:

$$
\begin{gathered}
G D P_{t}=\alpha_{1}+\sum_{i=1}^{p} \beta_{1 i} \text { INVtype }_{t-i}+\sum_{i=1}^{p} \gamma_{1 i} G D P_{t-1}+\varepsilon_{1 t} \\
\text { INVtype }_{t}=\alpha_{2}+\sum_{i=1}^{p} \beta_{2 i} G D P_{t-i}+\sum_{i=1}^{p} \gamma_{2 i} \text { INVtype }_{t-1}+\varepsilon_{2 t}
\end{gathered}
$$

Empirical estimates were obtained for quarterly data. Empirical estimates use GDP indicators and foreign capital inflows (separate models for studying the impact on GDP of direct, portfolio, and other investments) from the IMF World Economic Outlook Database and the IMF International Financial Statistics for the United Kingdom and Ireland (quarterly 2005-2019). As part of the construction of vector autoregression of time series, the mutual causality was tested separately between each type of foreign capital flows (FDI, portfolio, and other foreign investments) and GDP of countries. The results of the Granger test (Table 7) support the hypothesis of the impact of foreign investment flows on GDP.

An analysis of the results of modeling the dependence of GDP and capital flows obtained by the United Kingdom and Ireland during the study period shows that there is interdependence between Ireland's GDP and the country's capital flows from direct and portfolio investment. There is also a one-way dependence: in the UK, GDP growth depends on the inflow of portfolios into the country.

Conclusions. Examining the work of various authors, we can conclude that the impact of foreign investment on the economy is quite different. The processes of globalization have led to a rapid increase in foreign direct investment. Many authors pay attention to the consequences of investing in the country's economy. After studying various scientific studies, it was found that developed countries are less dependent on foreign direct investment than developing countries.

Table 6

The share of total income imported by national investors in the corresponding cumulative costs of the financial account (foreign investment coverage ratio), for the period 1999-2019

\begin{tabular}{|l|c|c|c|c|c|c|}
\hline \multicolumn{1}{|c|}{ Country } & FDI & Portfolio & Other & $\begin{array}{c}\text { Total imported } \\
\text { revenues, } \\
\text { billion dollars }\end{array}$ & $\begin{array}{c}\text { Cumulative costs } \\
\text { of the financial account, } \\
\text { billion dollars }\end{array}$ & $\begin{array}{c}\text { The share of imported } \\
\text { income in total costs }\end{array}$ \\
\hline United Kingdom & $73.75 \%$ & $79.02 \%$ & $274.82 \%$ & 5130.2 & 5145.8 & $99.7 \%$ \\
\hline Ireland & $111.90 \%$ & $30.51 \%$ & $39.07 \%$ & 1973.6 & 4098.6 & $48.15 \%$ \\
\hline
\end{tabular}

Source: author's calculations [7] 
Granger test for GDP (GDPt) and received capital flows (FDIt, PIt, OIt)

\begin{tabular}{|c|c|c|c|c|c|}
\hline \multirow{2}{*}{ Country } & \multirow{2}{*}{$\begin{array}{c}\text { The studied } \\
\text { indicator }\end{array}$} & \multicolumn{4}{|c|}{ Lags } \\
\hline & & GDP & FDI & PI & OI \\
\hline $\begin{array}{l}\text { United Kingdom } \\
\text { (2005-2019) }\end{array}$ & $\begin{array}{l}\text { GDP } \\
\text { FDI } \\
\text { PI } \\
\text { OI }\end{array}$ & $\begin{array}{l}2.06(0.72) \\
8.65(0.7)^{c} \\
0.08(0.95)\end{array}$ & $5.12(0.27)$ & $2.10(0.71)$ & $3.38(0.18)$ \\
\hline $\begin{array}{l}\text { Ireland } \\
(2005-2019)\end{array}$ & $\begin{array}{c}\text { GDP } \\
\text { FDI } \\
\text { PI } \\
\text { OI }\end{array}$ & $\begin{array}{l}3.63(0.60) \\
2.20(0.53) \\
0.47(0.49)\end{array}$ & $13.09(0.02)^{b}$ & $8.44(0.03)^{c}$ & $0.05(0.82)$ \\
\hline
\end{tabular}

Note: The sample range is indicated in parentheses after the country name. In parentheses, along with Wald-statistics, the values of the $\mathrm{P}$ - criterion are given: $\mathrm{a}, \mathrm{b}, \mathrm{c}-1 \%, 5 \%$ and $10 \%$ levels of significance, respectively (calculated by the author)

Source: author's calculations [7]

The effects of investment inflows on countries' economies differ in the short and long term. The authors found that investment is an important factor for economic growth in the long run, especially for developing countries. Investment inflows should be encouraged, but investment policies should be designed with a long-term perspective in mind to maximize the positive impact of investments on the country's economy. The positive impact of investment on countries with economies in transition was also identified, as the investment is an important source of funding for these countries, as it helps to cover the current account deficit.

In the United Kingdom, portfolio payouts predominate and account for $293.57 \%$ of the capital received. Investment payments on direct investments in the period 2005-2019 amounted to $177.66 \%$, the lowest percentage falls on investment payments on other investments $-82.99 \%$. In Ireland, investment payments for other investments predominate and this figure is $41.45 \%$ of the capital received. Payments on direct investments are $37.99 \%$ and the smallest share of payments falls on portfolio investments $-30.16 \%$.

After receiving the results of calculating the average value of the return on investment from 2005 to 2019, it was found that the highest return was received by foreign investors on direct investment in the UK (6.54\%). Foreign investors received the lowest returns from other investments in the UK, at $1.52 \%$. In turn, the return on the direct, portfolio, and other investments in Ireland is almost at the same level.

Based on the obtained calculations, the highest return on foreign investment for the study period 2005-2019 was obtained by British investors on direct investment abroad $(6.54 \%)$. The rate of return on direct investment in Ireland is $5.27 \%$. The least British investors received from other investments; this figure is $1.52 \%$. Therefore, it should be concluded that investors in the UK and Ireland have the highest returns on foreign direct investment abroad.

An analysis of the results of modeling the dependence of GDP and capital flows obtained by the United Kingdom and Ireland during the study period shows that there is interdependence between Ireland's GDP and the country's capital flows from direct and portfolio investment. There is also a one-sided dependence in the UK, namely GDP growth depends on the inflow of portfolio investment into the country.

\section{References:}

1. Shaveta Gupta (2013) Impact of Foreign Investments on Stock Market Volatility: An Evidence from Indian Stock Market / Shaveta Gupta, Neha Kalra, Rajesh Bagga. LMA Effective Management, pp. 1-11. Available at: https://www.researchgate.net/ publication/336121795_Impact_of_Foreign_Investments_on_Stock_Market_Volatility_An_Evidence_from_Indian_Stock_ Market (accessed 8 November 2020).

2. Suzana Djordjevic (2015) Direct Foreign Investment and the Lack of Positive Effects on the Economy / Suzana Djordjevic, Zoran Ivanovic, and Sinisa Bogdan. UTMS Journal of Economics, no. 6 (2), pp. 197-208. Available at: http://www.utmsjoe.mk/files/ Vol.\%206\%20No.\%202/UTMSJOE-2015-0602-002-Djordjevic-Ivanovic-Bogdan.pdf (accessed 8 November 2020).

3. Eduard Davletshin (2015) Quantitative and Qualitative Analysis of Foreign Direct Investments in Developed and Developing Countries / Eduard Davletshin, Svetlana Kotenkova, Efremov Vladimir. Procedia Economics and Finance, vol. 32, pp. $256-263$. Available at: https://www.sciencedirect.com/science/article/pii/S2212567115013891 (accessed 10 November 2020).

4. Trang Thi-Huyen Dinh (2019) Foreign Direct Investment and Economic Growth in the Short Run and Long Run: Empirical Evidence from Developing Countries / Trang Thi-Huyen Dinh, Duc Vo, Anh The Vo, Thang Cong Nguyen. Journal of Risk and Financial Management, vol. 12, issue 4, pp. 1-11. Available at: https://www.researchgate.net/publication/337497178_Foreign Direct_Investment_and_Economic_Growth_in_the_Short_Run_and_Long_Run_Empirical_Evidence_from_Developing Countries (accessed 10 November 2020).

5. Libor Krkoska (2002) Foreign Direct Investment Financing of Capital Formation in Central and Eastern Europe. European Bank for Reconstruction and Development (EBRD) Working Paper, no. 67, pp. 1-19. Available at: https://www.ebrd.com/downloads/ research/economics/workingpapers/wp0067.pdf (accessed 10 November 2020).

6. Rodionova T.A. (2015) Dokhidnist inozemnykh investytsii v krainakh z rynkom, shcho formuietsia: vplyv na zovnishni dysbalansy: monografiia [Return on foreign investment in emerging markets: the impact on external imbalances: a monograph] Odesa : "Odesa I.I. Mechnikov National University" 2015. Pp. 41-50. Available at: http://fs.onu.edu.ua/clients/client11/web11/pdf/rodion-inozinvest.pdf (accessed 15 November 2020).

7. International Monetary Fund (2020) Databases. Available at: https://www.imf.org/en/Data (accessed 15 November 2020). 


\section{Список використаних джерел:}

1. Shaveta Gupta. Impact of Foreign Investments on Stock Market Volatility: An Evidence from Indian Stock Market / Shaveta Gupta, Neha Kalra, Rajesh Bagga. LMA Effective Management. 2013. P. 1-11. URL: https://www.researchgate.net/publication/336121795_Impact_of_Foreign_Investments_on_Stock_Market_Volatility_An_Evidence_from_Indian_Stock_Market (дата звернення 08.10.2020).

2. Suzana Djordjevic. Direct Foreign Investment and the Lack of Positive Effects on the Economy / Suzana Djordjevic, Zoran Ivanovic, and Sinisa Bogdan. UTMS Journal of Economics. 2015. № 6 (2). P. 197-208. URL: http://www.utmsjoe.mk/files/Vol.\%20 6\%20No.\%202/UTMSJOE-2015-0602-002-Djordjevic-Ivanovic-Bogdan.pdf (дата звернення 08.10.2020).

3. Eduard Davletshin. Quantitative and Qualitative Analysis of Foreign Direct Investments in Developed and Developing Countries / Eduard Davletshin, Svetlana Kotenkova, Efremov Vladimir. Procedia Economics and Finance. 2015. Vol. 32, pp. $256-263$. URL: https://www.sciencedirect.com/science/article/pii/S2212567115013891 (дата звернення 10.10.2020).

4. Trang Thi-Huyen Dinh. Foreign Direct Investment and Economic Growth in the Short Run and Long Run: Empirical Evidence from Developing Countries / Trang Thi-Huyen Dinh, Duc Vo, Anh The Vo, Thang Cong Nguyen. Journal of Risk and Financial Management. 2019. Vol. 12, issue 4, pp. 1-11. URL: https://www.researchgate.net/publication/337497178_Foreign_Direct Investment_and_Economic_Growth_in_the_Short_Run_and_Long_Run_Empirical_Evidence_from_Developing_Countries (дата звернення 10.10.2020).

5. Libor Krkoska. Foreign Direct Investment Financing of Capital Formation in Central and Eastern Europe. European Bank for Reconstruction and Development (EBRD) Working Paper. 2002. No. 67, pp. 1-19. URL: https://www.ebrd.com/downloads/ research/economics/workingpapers/wp0067.pdf (дата звернення 10.10.2020).

6. Родіонова Т.А. Дохідність іноземних інвестицій в країнах 3 ринком, що формується: вплив на зовнішні дисбаланси :монографія. Одеса : «Одеський національний університет імені I.I. Мечникова», 2015. C. 41-50. URL: http://fs.onu.edu.ua/clients/client11/web11/pdf/rodion-inoz-invest.pdf (дата звернення 15.10.2020).

7. International Monetary Fund (2020) Databases. URL: https://www.imf.org/en/Data (дата звернення 15.10.2020).

\section{АНАЛІЗ ПРИБУТКОВОСТІ ІНОЗЕМНИХ ІНВЕСТИЦІЙ У ВЕЛИКІЙ БРИТАНІЇ ТА ІРЛАНДІЇ}

Анотація. Міжнародні потоки капіталу мають значні потенційні вигоди для економік всього світу. 3 посиленням процесів глобалізації та збільшенням масштабів міжнародного руху капіталу роль прямих іноземних інвестицій як важливого чинника економічного розвитку значно зростає. За рахунок залучення іноземних інвестицій з'являються можливості для оновлення та модернізації виробництва, створення додаткових робочих місць, збільшення податкових надходжень і загального підвищення конкурентоспроможності національної економіки. У статті аналізуються теоретичні основи аналізу прибутковості прямих інвестицій, визначені коефіцієнти покриття іноземних інвестицій, які були залучені в країни та експортовані з країн. Також була визначена дохідність залучених та експортованих інвестицій. Після отримання результатів розрахунку середнього значення прибутковості інвестицій за період 32005 по 2019 роки було встановлено, що найбільша прибутковість була отримана іноземними інвесторами від прямих інвестицій в Великій Британії. Іноземні інвестори отримали найнижчу дохідність від інших інвестицій у Велику Британію. Однак прибутковість прямих, портфельних та інших інвестицій в Ірландії майже на одному і тому ж рівні. Найвищий дохід від іноземних інвестицій було отримано британськими інвесторами від прямих інвестицій за кордон в 2005-2019 роках. Норма повернення прямих інвестицій в Ірландію становить 5,27\%. Найменше британські інвестори отримали від інших інвестицій. Інвестори як у Великій Британії, так і в Ірландії мають найвищий дохід від прямих іноземних інвестицій за кордоном. Проведено емпіричний аналіз залежності ВВП від потоків капіталу, отриманого країнами від прямих, портфельних та інших інвестицій. Аналіз результатів моделювання залежності ВВП і потоків капіталу, отриманих Великою Британією та Ірландією за досліджуваний період, показує, що існує взаємозалежність між ВВП Ірландії і потоками капіталу країни як від прямих, так і від портфельних інвестицій. Також існує однобічна залежність: у Великій Британії зростання ВВП залежить від припливу портфельних інвестицій в країну.

Ключові слова: Велика Британія, прямі інвестиції, Ірландія, портфельні інвестиції, рентабельність інвестицій, інші інвестиції

\section{АНАЛИЗ ДОХОДНОСТИ ИНОСТРАННЫХ ИНВЕСТИЦИЙ В ВЕЛИКОБРИТАНИИ И ИРЛАНДИИ}

Аннотация. Международные потоки капитала имеют значительные потенциальные выгоды для экономик всего мира. С усилением процессов глобализации и увеличением масштабов международного движения капитала роль прямых иностранных инвестиций как важного фактора экономического развития значительно возрастает. За счет привлечения иностранных инвестиций появляются возможности для модернизации производства, создания дополнительных рабочих мест, увеличения налоговых поступлений. В статье анализируются теоретические основы анализа рентабельности инвестиций, определяемые коэффициентами покрытия иностранных инвестиций, которые были привлечены в страны и вывезены из стран. Также была определена окупаемость инвестиций. Анализ результатов моделирования зависимости ВВП и потоков капитала, полученных Соединенным Королевством и Ирландией за исследуемый период, показывает, что существует взаимозависимость между ВВП Ирландии и потоками капитала страны как от прямых, так и от портфельных инвестиций.

Ключевые слова: Великобритания, прямые инвестиции, Ирландия, портфельные инвестиции, рентабельность инвестиций, прочие инвестиции. 